\title{
ANALISA STRUKTUR REGIONAL PENYEBAB GEMPA DAN TSUNAMI BERDASARKAN ANOMALI GRAVITASI DAN DINAMIKA LEMPENG
}

\author{
Nur Rochman Muhammad, Wien Lestari, Firman Syaifuddin \\ Teknik Geofisika, Fakultas Teknik Sipil dan Perencanaan, Institut Teknologi Sepuluh Nopember \\ e-mail : nurrochmanmuhammad@gmail.com
}

\begin{abstract}
Abstrak. Peristiwa gempa bumi dan Tsunami merupakan bencana yang tidak bisa dihindari oleh masyarakat Indonesia sebagai negara yang terletak pada jalur tektonik aktif dunia. Akibat adanya pertemuan lempeng Indo-Australia pada daerah bagian Selatan Indonesia, menyebabkan kawasan ini memiliki nilai seismitas yang cukup tinggi. Salah satu kawasan yang sering terjadi peristiwa gempa dan Tsunami yaitu berada di jalur subduksi Sunda. Pada kawasan ini, terjadi beda densitas subduksi antara Pulau Jawa dan Pulau Sumatera akibat adanya perbedaan gaya kompresi pada kedua kawasan tersebut. Perbedaan densitas subduksi diketahui dari inversi data anomali gravitasi pada jalur subduksi Sunda untuk mengintepretasikan struktur regional pada area yang pernah terjadi gempa besar yang menyebabkan Tsunami. Setelah dilakukan inversi 2D terhadap data gravity pada tujuh lintasan yang searah dengan arah subduksi di jalur Sunda, dimana line 4 di daerah Jawa dan line 5 sampai 7 di daerah Sumatera. Didapatkan beda densitas pada line 1 sebesar $-0.24 \sim-0.26 \mathrm{~g} / \mathrm{cm}^{3}$; line 2 sebesar $-0.25 \sim-0.5$ $\mathrm{g} / \mathrm{cm}^{3}$; line 3 sebesar $-0.3 \sim-0.5 \mathrm{~g} / \mathrm{cm}^{3}$; line 4 sebesar $-0.19 \sim-0.24 \mathrm{~g} / \mathrm{cm}^{3}$; line 5 sebesar $-0.3 \sim-0.55$ $\mathrm{g} / \mathrm{cm}^{3}$; line 6 sebesar $-0.1 \sim-0.26 \mathrm{~g} / \mathrm{cm}^{3}$ dan line 7 sebesar $-0.05 \sim-0.2 \mathrm{~g} / \mathrm{cm}^{3}$. Berdasarkan beda densitas ini, diketahui bahwa daerah Jawa memiliki beda densitas lebih besar karena laju subduksi lebih tinggi dibandingkan daerah Sumatera.
\end{abstract}

Kata Kunci: gravity, inversi, densitas, Tsunami

Abstract. The earthquake and Tsunami are disasters that can not be avoided by the people of Indonesia as a country on active tectonic area. As a result of their meetings in the region Indo-Australia plate southern part of Indonesia, causing this area has a high seismic event. One area that frequent earthquake and Tsunami events are in the path of the Sunda subduction. In this area, there was a subduction causing density difference between Java and Sumatra as a result of differences in compression forces on the two regions. If an area of a subduction zone has a relatively high density it will have the potential to release energy from the quake relatively greater if it is supported by a local fault structures that already exist. To determine the density difference in subduction zone we use gravity anomaly data at Sunda subduction path to interpret regional structures in the area that have occurred massive earthquake that caused the Tsunami. After the 2D inversion of the gravity data on seven tracks in the direction of the Sunda subduction path, where four inversion line in the area of Java and line 5 to 7 in the area of Sumatra. Obtained different density on line 1 of $-0.24 \sim-0.26 \mathrm{~g} / \mathrm{cm}^{3}$; line 2 amounted to $-0.25 \sim-0.5 \mathrm{~g} / \mathrm{cm}^{3}$; line 3 of $-0.3 \sim-0.5 \mathrm{~g} / \mathrm{cm}^{3}$; line 4 at $-0.19 \sim-0.24 \mathrm{~g} / \mathrm{cm}^{3}$; line 5 of $-0.3 \sim-0.55 \mathrm{~g} / \mathrm{cm}^{3}$; line 6 of $-0.1 \sim-0.26 \mathrm{~g} /$ $\mathrm{cm}^{3}$ and line 7 of $-0.05 \sim-0.2 \mathrm{~g} / \mathrm{cm}^{3}$. Based on the density difference, it is known that Java has a density greater difference, assume is subduction rate is higher than the area of Sumatra.

Keywords: gravity, inversion, density, Tsunami

\section{PENDAHULUAN}

Pola distribusi densitas pada zona subduksi bisa didapatkan dengan metoda gravitasi yang kemudian di lakukan inversi menjadi densitas. Densitas tersebut dapat juga membantu untuk mendeliniasi secara lokal busur subduksi yang telah terbentuk. Hal tersebut dapat menunjukkan struktur dominan yang telah terbentuk dengan dikorelasikan dengan kondisi pada permukaan tanah. Dimana serangkaian analisa diatas dapat digunakan untuk mengetahui potensi dari kegempaan dipulau Jawa.

Hal tersebut dilandasi asumsi penulis yaitu pada zona subduksi akan terjadi pressure yang tinggi yang dapat mengubah (memampatkan, memadatkan) yang akan meningkatkan densitas dari densitas awal mula. Dimana jika suatu daerah pada zona zubduksi memiliki densitas yang relatif tinggi maka akan memiliki potensi release energy dari gempa yang relatif lebih besar jika didukung 
dengan struktur patahan lokal yang telah ada. Disisi lain perlu juga dipertimbangkan dari data kejadiankejadian gempa yang telah terjadi pada zona subduksi.

Oleh karena itu diperlukan penelitian lebih lanjut untuk mengetahui pengaruh dari gravitasi di sekitar zona subduksi, untuk membuktikan apakah benar-benar ada pengaruh yang signifikan dari anomali gravitasi pada zona subduksi terhadap kuat gempa.

Kolektifitas dari data yang digunakan adalah data bouguer gravitasi dari website (topex.ucsd.edu) atau data online lainnya, peta geologi pulau jawa, topografi laut dan titik koordinat gempa yang telah terjadi sebelumnya (IRIS). Yang kemudian akan dilakukan pengolahan pada data bouguer gravitasi meliputi separasi anomali residual-anomali regional yang dapat dianalisa langsung.

Pada metoda gravitasi akan di dapatkan $\mathrm{g}$ observasi yang akan dilakukan penghitungan dengan koreksi secara teoritis yang akan menghasilkan anomali bouguer yaitu anomali yang bersumber dari semua perlapisan di bawah perukaan yaitu gabungan dari anomali regional dan anomali residual. Anomali regional adalah komponen yang memberikan informasi mengenai benda-benda sumber anomali pada kedalaman yang dalam, bersifat smooth dan mempunyai frekuensi yang rendah, sedangkan anomali residual mempunyai frekuensi tinggi yang merepresentasikan bendabenda sumber anomali pada kedalaman yang dangkal. Dalam eksplorasi, data yang digunakan dalam pemodelan dapat menggunakan data anomali residual dikarenakan pada eksplorasi wilayah interest berada pada kedalaman yang dangkal. Untuk mendapatkan data anomali residual, maka perlu dilakukan proses separasi regional-residual dari data anomali Bouguer. Oleh karena itu proses separasi regionalresidual merupakan tahap yang sangat penting dalam memperoleh data anomali lokal karena dapat mempengaruhi proses interpretasi dan pemodelan baik 2D.

Kemudian inversi dan modelling dari data gravitasi dilakukan untuk mengetahui densitas dari batuan pada zona subduksi. Setelah itu di lakukan korelasi dengan struktur patahan dan letak gempa sebelumnya. Kemudian dapat dilakukan analisa dari peta geologi pulau jawa yang dapat dikorelasikan dengan geodinamika dari pergerakan lempeng mayor di Indonesia. Pada IRIS dapat diketahui mekanisme vokal dari gempa yang dapat di intepretasikan ke struktur penyebab gempa tersebut.Diharapkan hasil dari analisa nantinya dapat menunjukkan daerah rawan yang perlu dilakukan mitigasi yang lebih intensif terhadap ancaman gempa dan bencana Tsunami mengingat Indonesia banyak terjadi gempa di laut. Serta menambahkan informasi pada pembuatan peta rawan bencana gempa dan Tsunami.

\section{METODOLOGI}

Tahapan yang digunakan dalam paper ini adalah sebagai berikut,

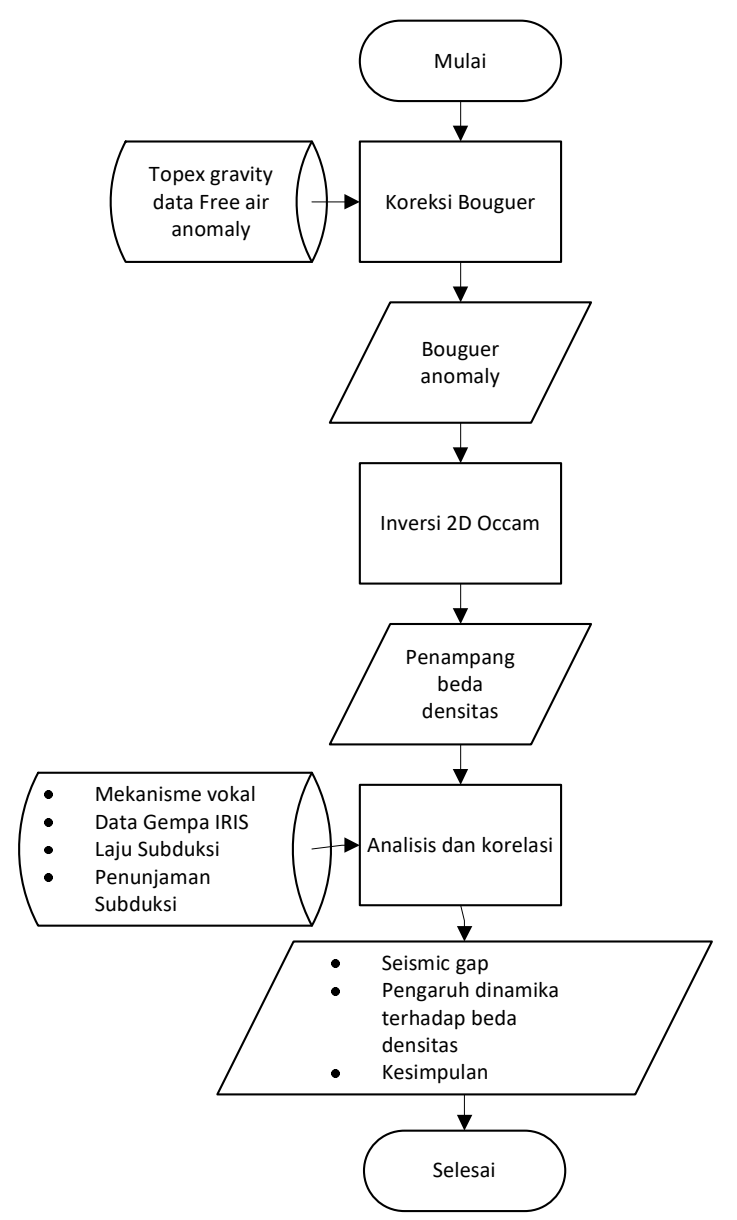

Gambar 1. Diagram alir penelitian. 
Selain dari kuat magnitud gempa(Mw $\geq 7)$ Tsunami juga disebabkan oleh letak kedalaman gempa dan posisi terhadap busur penunjaman.

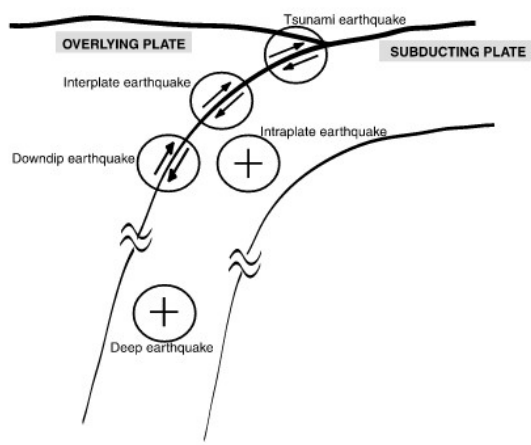

Gambar 2. Macam-macam Letak gempa pada zona subduksi oleh Venkataraman Kanamori.

Dari Gambar 2. dapat diketahui bahwa Tsunami digenerasikan oleh gempa relatif dangkal lebih tepatnya di accretional wedges pada zona subduksi. Dalam klasifikasi peta gempa Indonesia gempa dangkal adalah 0-90 km, sedangkan untuk Tsunami berkisar antara kedalaman hiposentrum 0$20 \mathrm{~km}$.

Proses generasi gelombang Tsunami yang diakibatkan thrust fault berturut-turut dari gaya kompresi-akumulasi energi-release dalam bentuk deformasi thrust fault,

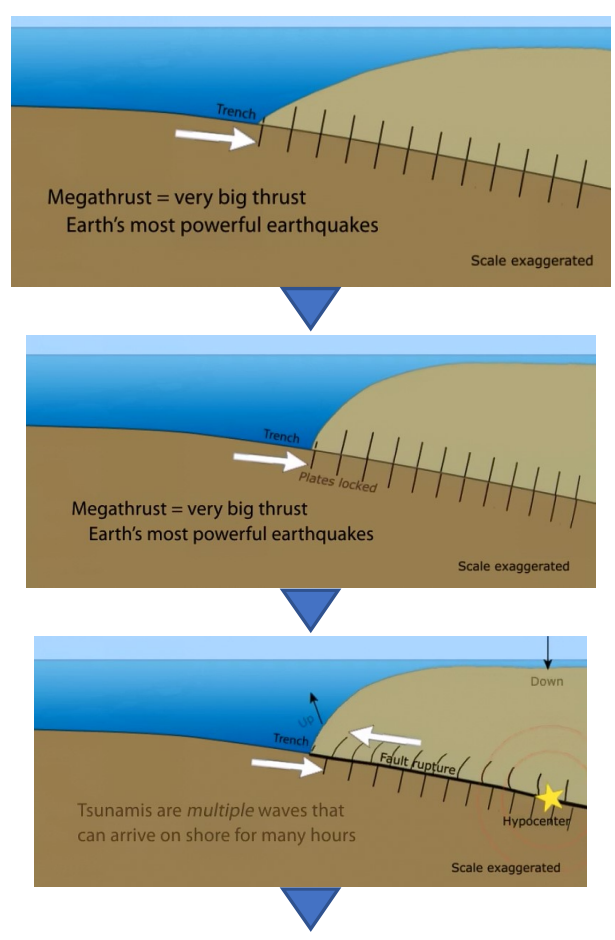

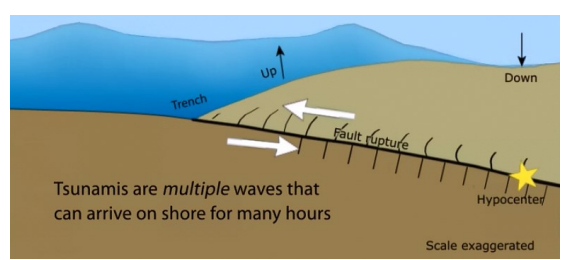

Gambar 3. tahapan generasi gelombang Tsunami pada patahan naik, sumber www.iris.edu.

Untuk memperkirakan stress yang terjadi pada thrust fault

$$
\sigma_{2}=\sigma_{a}=\sigma_{1}\left[\begin{array}{c}
v \\
1-n
\end{array}\right]
$$

Jika v adalah Poisson's ratio sebesar 0.25 untuk batuan. Maka dalam litosfer yang bersifat elastis, $\sigma_{1}=3 \sigma_{2}$

Kemudian disubtitusikan antara koponen stress, untuk mengetahui kondisi yang menyebabkan patahan terjadi (kompresi),

Dengan,

$$
\left(\sigma_{V}-\sigma_{h}\right)-\rho g z-3 \rho g z--2 \rho g z
$$

$\rho=$ densitas lempeng (dimisalkan $2670 \mathrm{~kg} / \mathrm{m}^{3}$ )

$g=$ konstanta gravitasi (dimisalkan $9,81 \mathrm{~m} / \mathrm{s}^{2}$ )

$\mathrm{z}=$ kedalaman $(\mathrm{m})$

Dari permisalan diatas akan timbul thrust fault apabila stress arah horisontal $\sigma_{\mathrm{k}}$ lebih besar daripada tekanan vertikal $\sigma_{v}$. Kemudian didapatkan grafik $\left(\pi_{v}-\pi_{k}\right)$ dalam variasi kedalaman dari 0-90 $\mathrm{km}$ untuk memperkirakan berapa besar tekanan yang dibutuhkan untuk menyebabkan thrust fault,

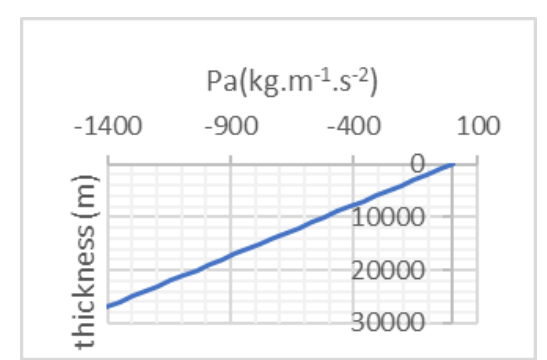

Gambar 4. kompresi yang dibutuhkan dalam menyebabkan patahan.

Grafik diatas adalah grafik dimana kondisi ideal untuk tekanan yang dibutuhkan untuk mematahkan benda dengan densitas yang telah ditentukan, jadi untuk kondisi nyata akan berbeda dan lebih kecil tekanan yang dibutuhkan karena ada pengaruh dari porositas dan rigiditas. Untuk grafik diatas hanya untuk menunjukkan pengaruh densitas terhadap pressure yang dibutuhkan untuk membuat patah suatu material. 
Kemudian untuk melihat penampang densitas perlu dilakukan pengolahan data gravitasi menjadi beda densitas. Dibawah ini adalah peta free-air anomaly,

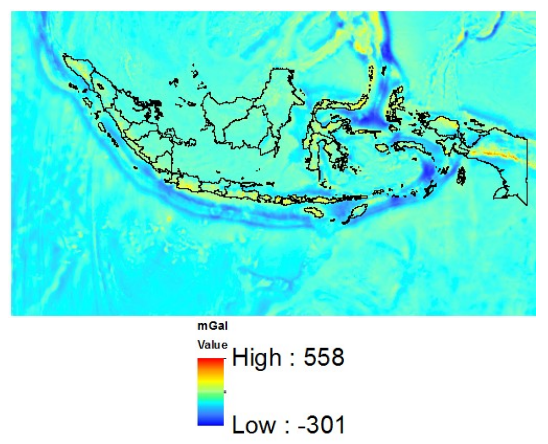

Gambar 5. Anomali gravitasi free air Indonesia, sumber data topex.ucs.edu.

Anomali gravitasi yang didapatkan adalah anomali gravitasi free-air jadi belum dalam anomali Bouguer. Jadi perlu dilakukan koreksi Bouguer untuk mendapatkan anomali Bouguer,

$$
\Delta G_{B}=\Delta G_{F A}-2 \pi \rho G H
$$

Dengan ,

$\Delta G_{F A}=$ free air anomaly (mGal)

$\rho=$ Densitas rata-rata bumi $2670 \mathrm{~kg} / \mathrm{m}^{3}$

$\mathrm{G}=$ Konstanta gravitasi universal 6,673 x 10

${ }^{8} \mathrm{~m}^{3} \mathrm{~kg}^{-1} \mathrm{~s}^{-2}$

$\mathrm{H}=$ selisih topografi dengan geoid $(\mathrm{m})$

Atau dalam bentuk lebih sederhananya,

$\Delta G_{B}=\Delta G_{F A}-0.1119 \mathrm{H}$

Untuk peta selisih topografi dengan geoid adalah sebagai berikut ini,

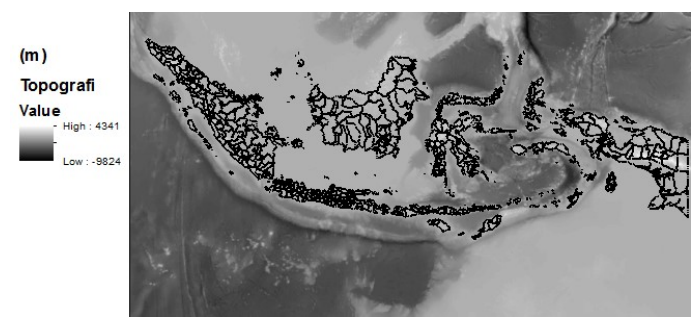

Gambar 6. Peta selisih topografi dengan geoid,sumber topex.ucs.edu.

Maka data anomali yang didapat dari topex.ucs.edu yang telah dilakukan dilakukan koreksi adalah sebagai berikut,

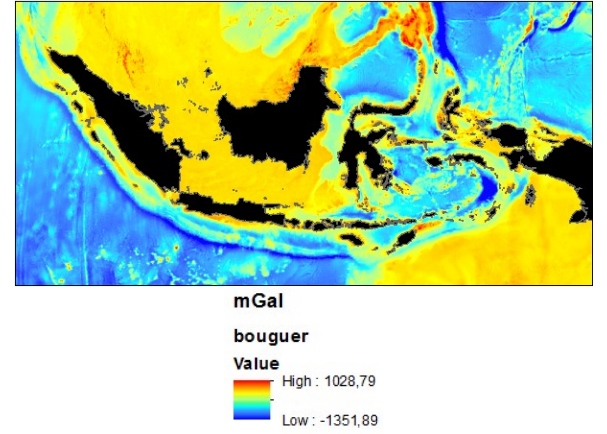

Gambar 7. Anomali gravitasi Bouguer Indonesia.

Dengan begitu dapat diketahui beda densitas $\Delta \rho$ dengan inversi dari anomali Bouguer. Dalam data gravitasi dari satelit ini memiliki kelemahan dalam resolusinya untuk menentukan skala meter, tetapi masih relatif baik untuk skala kilometer.

\section{HASIL DAN PEMBAHASAN}

Bagian Pembahasan kami detailkan dalam beberapa sub bab yang berbeda

\section{Proses Inversi}

Inversi dilakukan dibeberapa line yang memotong garis subduksi yang dianggap memiliki anomali gravitasi tinggi dibanding sekitarnya pada zona subduksi tersebut.

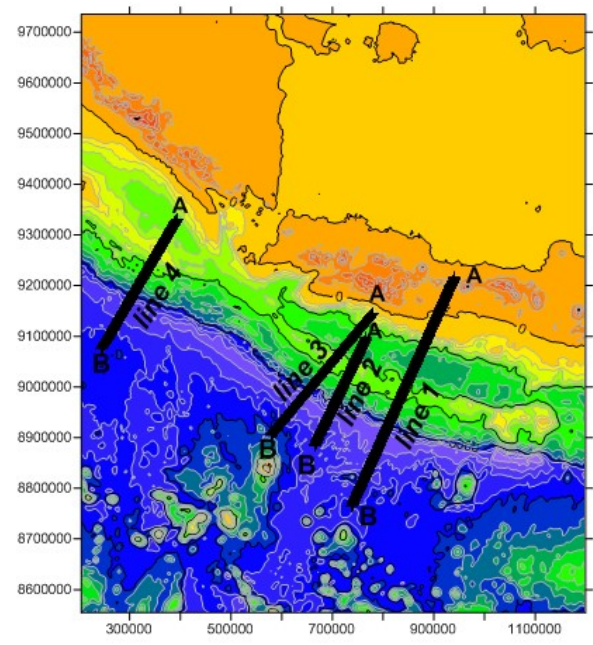

Gambar 8. Slice line 1,2,3 dan 4 dilakukan pada subduksi di Jawa

Slicing dilakukan pada zona subduksi yang pernah menghasilkan gempa yang menimbulkan Tsunami Pangandaran (Mw 7.2) pada 2006-07-17. Hal ini dilakukan untuk mengidentifikasi area tersebut dari segi kontras densitas. 


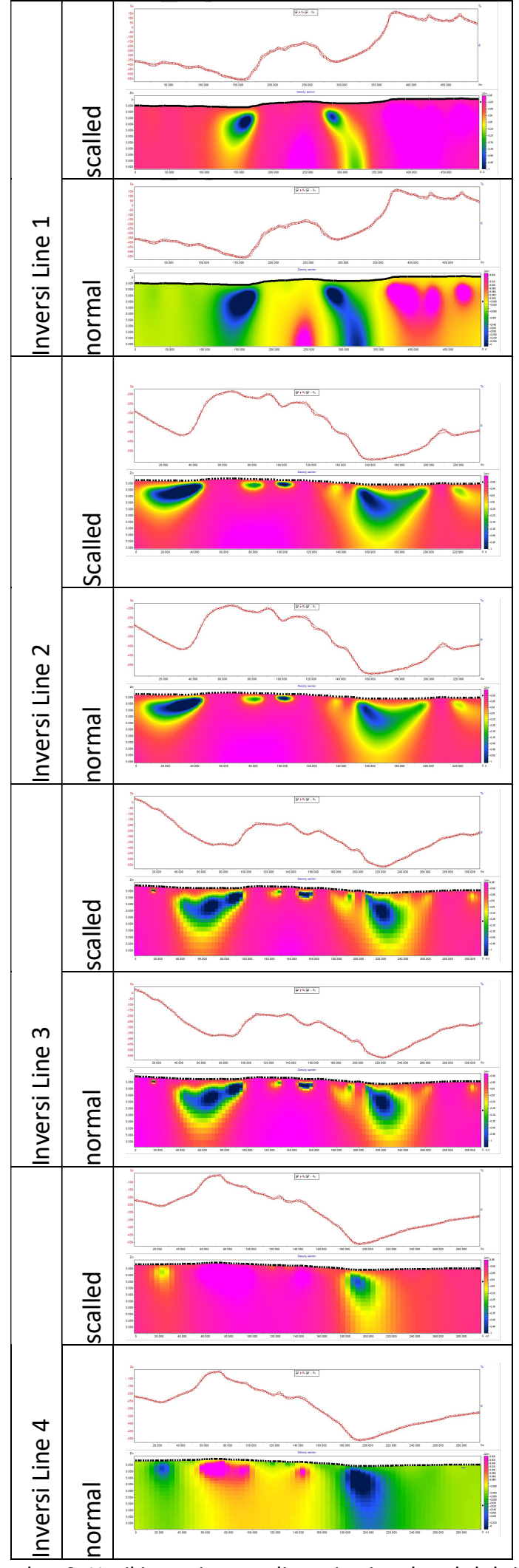

Gambar 9. Hasil inversi anomali gravitasi pada subduksi di Jawa.
Kemudian untuk subduksi pada Sumatra dilakukan tiga slicing masing masing terletak pada zona yang memiliki gempa-gempa besar,
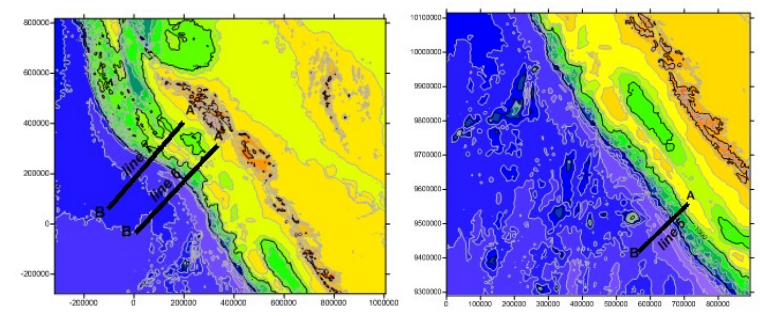

Gambar 10. Slicing pada subduksi pada Sumatra

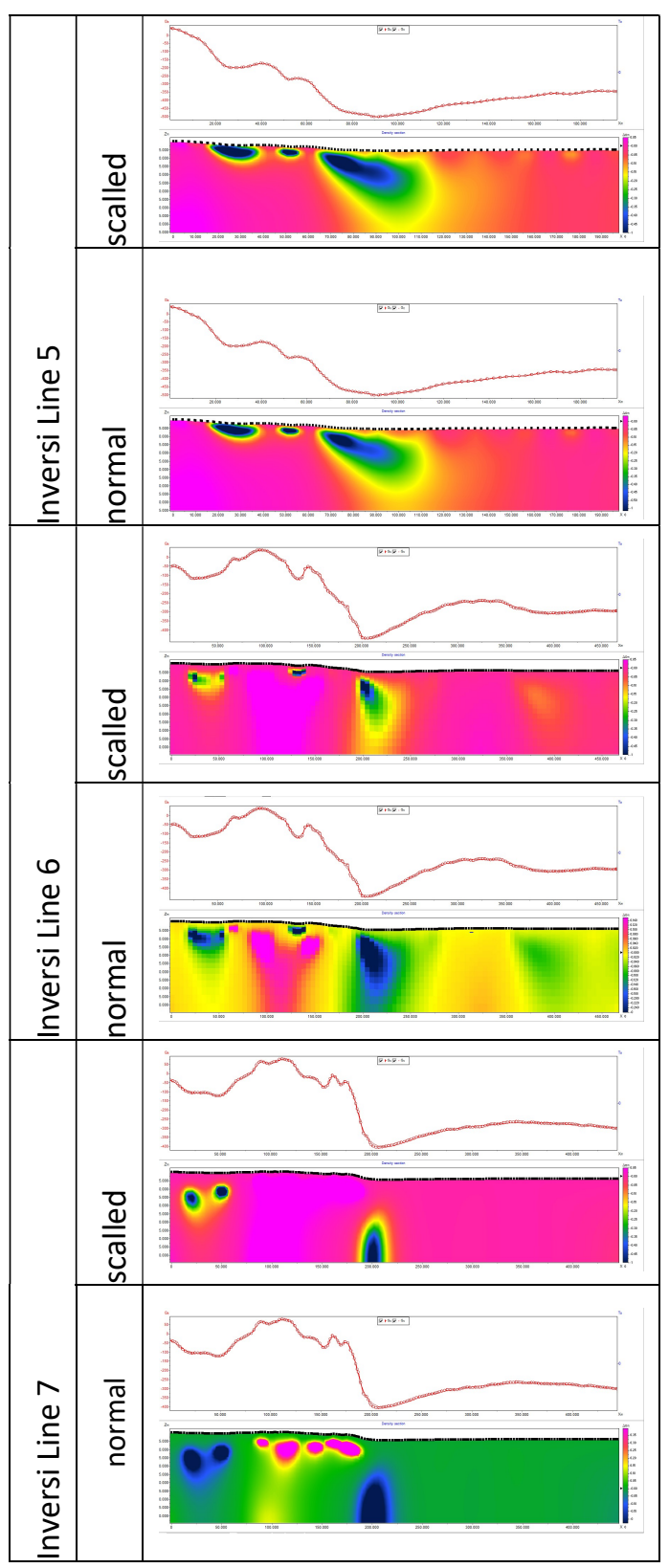

Gambar 11. Hasil inversi anomali gravitasi pada subduksi di Sumatra 
Dari hasil inversi tersebut didapatkan beda densitas dari tiap line subduksi,

Tabel 1. Beda densitas pada line subduksi dalam $\mathrm{g} / \mathrm{cm}^{3}$

\begin{tabular}{|l|l|l|}
\hline Zone & Line & Density Contrast \\
\hline Jawa & Line 1: & $-0.24^{\sim}-0.26$ \\
& Line 2: & $-0.25^{\sim}-0.5$ \\
& Line3: & $-0.3^{\sim}-0.5$ \\
& Line 4: & $-0.19^{\sim}-0.24$ \\
\hline Sumatra & Line 5: & $-0.3^{\sim}-0.55$ \\
& Line 6: & $-0.1^{\sim}-0.26$ \\
& Line 7: & $-0.05^{\sim}-0.2$ \\
\hline
\end{tabular}

Setelah didapatkan beda densitas pada tiap subduksi bisa dilakukan analisa bahawa pada zona subduksi di Jawa lebih besar beda densitasnya dibandingkan dengan subduksi di Sumatra. Jika kita amati pada gambar pergerakan lempeng di subduksi sunda dibawah ini,

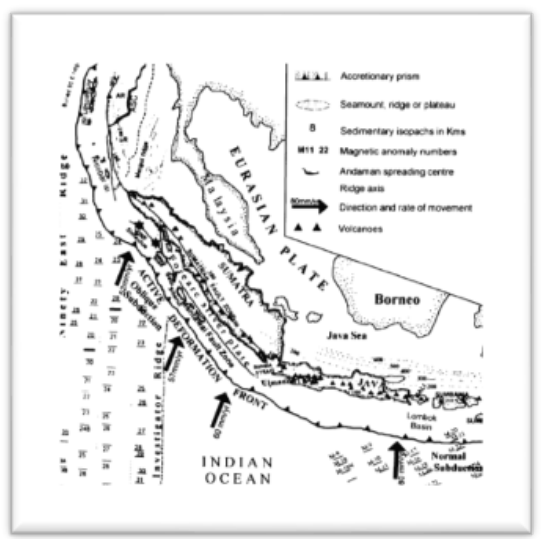

Gambar 12. Laju Subduksi Sunda pada beberapa titik.

Dapat dilihat bahwa laju subduksi di Jawa lebih cepat dibandingkan di Sumatra ,hal ini yang menyebabkan pengaruh pada kompresi yang dilakukan uleh lempeng Indo-Australi terhadap Lempeng Eurasia lebih intens di zona subduksi di Jawa sehingga menyebabka penurunan densitas yang relatif tinggi. Namun gempa yang terjadi lebih sedikit jika dibandingkan gempa pada jalur subduksi di Sumatra, dimana hal ini dikarenakan orientasi interaksi lempeng berbeda dimana strike slip fault akan lebih mudah menggenerasikan gempa.

Analisis Hiposentrum dan Magnitud Gempa

Berikut ini adalah bentukan subduksi sunda ,

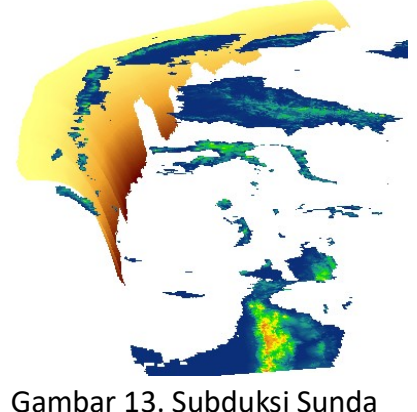

Subduksi tersebut mencapai kedalaman $600 \mathrm{~km}$ untuk zona Jawa, hal ini juga dipengaruhi oleh dinamika lempeng Eurasia dan Indo-Australi memiliki laju subduksi hingga $6 \mathrm{~cm} /$ tahun.

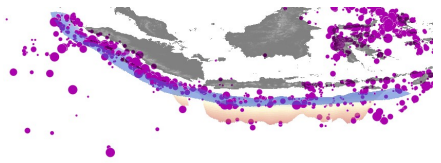

Gambar 14. Gempa dari 1990-01-06 sampai dengan 2016-10-19 dengan $\mathrm{Mw}>5$

Pada gambar tersebut terlihat bahwa gempa lebih banyak pada kedalaman $20 \mathrm{~km}-60 \mathrm{~km}$. Yang berarti gempa dangkal lebih banyak terjadi dari pada gempa dalam dan beberapa gempa memiliki $\mathrm{Mw}>7$,

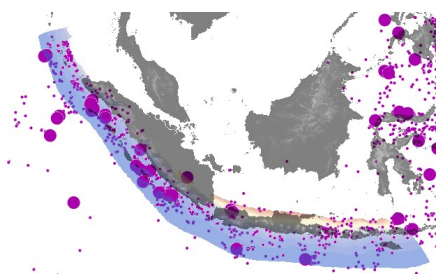

Gambar 15. Gempa dengan Mw > 7 (lingkaran besar).

Bahayanya gempa tersebut termasuk gempa dangkal, terdapat dua gempa yang menghasilkan Tsunami besar, 


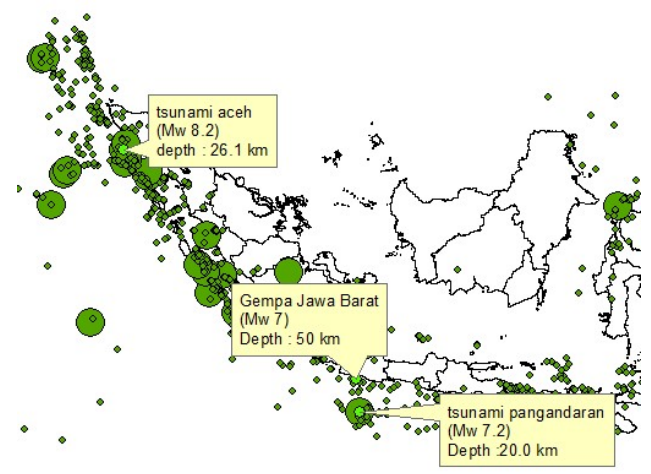

Gambar 16. Tsunami yang disebabkan oleh gempa dangkal

Pada subduksi di Sumatra lebih kaya akan gempa dangkal yang lebih membahayakan dan berpotensi terjadi Tsunami dibandingkan di Jawa.

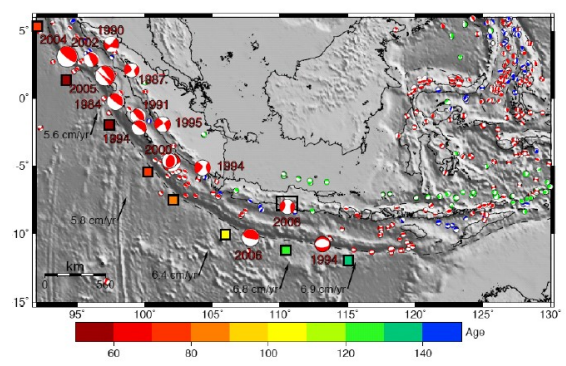

Gambar 17. Mekanisme Vokal gempa pada subduksi Sunda (Nurraini, 2014)

Terlihat pada Sumatra Utara, Sumatra Barat, dan gempa Pangandaran dari gambar tersebut mekanisme vokal gempa dangkal adalah thrus-fault dimana sebelumnya telah dibahas bahwa gempa ini yang sering menyebabkan Tsunami.

\section{Analisa Seismic Gap}

Seismic gap adalah bagian dari suatu zona patahan yang sepi gempa untuk jangka waktu cukup lama. Hal ini bisa diartikan bahwa ada kemungkinan pada seismic gap ini terjadi akumulasi tekanan tektonik dalam jumlah besar yang siap untuk dimuntahkan sebagai gempa besar. (Danny.,2009) Dibawah ini adalah pekiraan posisi seismic gap dengan metoda kernel density dari gempa-gempa yang telah terjadi,

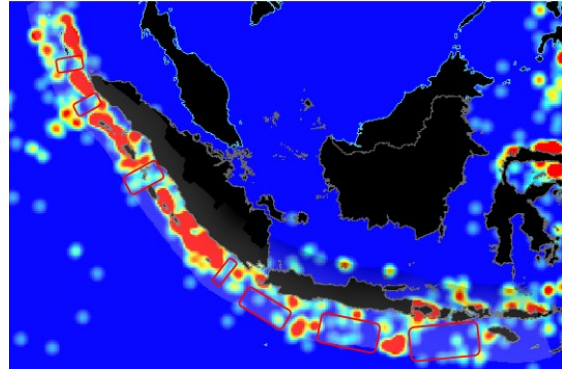

Gambar 18. Perkiraan Seismic Gap pada jalur subduksi

\section{PENUTUP}

\section{Simpulan}

Dari analisa diatas dapat ditarik kesimpulan sebagai berikut ini,

1. Kontras densitas menunjukkan pengaruh dari laju subduksi, apa bila memiliki kontras densitas rendah (range negatif) maka laju subduksi relatif lambat bila dibandingkan laju subduksi pada zona beda densitas yang besar (range negatif).

2. Slab subduksi dapat diketahui dengan letak sumber gempa.

3. Subduksi di zona Sumatra lebih beresiko mengakibatkan Tsunami pada analisa seismic gap dan kedalaman persebaran beda densitas yang dangkal bila dibandingkan pada subduksi Jawa.

4. Penunjaman telah mencapai kedalaman $>600 \mathrm{~km}$ di Selatan Jawa berdasarkan letak hiposentrum.

\section{Saran}

Perlu dilakukan inversi model bawah permukaan area subduksi dengan metode waveform inversion dikarenakan metoda tersebut memiliki resolusi yang baik. Dengan gambaran bawah permukaan yang lebih baik diharapkan dapat menginformasikan letak potensi gempa yang membahayakan (menimbulkan Tsunami).

\section{DAFTAR PUSTAKA}

Anupama.V dan H.Kanamori. (2004). Observational constraints on the fracture energy of subduction zone earthquakes.Journal Of Geophysical Research.Vol. 10. 
Danny,H,N.(2009). Gempa Besar 2 September 2009 (7.3 SR) di Wilayah Jawa Barat. Press Release IAGI:Jakarta.

Lasitha,S.(2007). Geodynamics of the Andaman Sumatra - Java Trench - Arc System Based on Gravity and Seismotectonic Study.University of Science and Technology:India.

Nuraini,R,H.(2014). Interplate Earthquake Potential off Western Java, Indonesia, based on GPS data.Nagoya University:Japan.

http://iris.edu/ (4 Juli 2017)

http://topex.ucsd.edu/ (4 Juli 2017)

https://earthquake.usgs.gov/ (4 Juli 2017)

http://seismo.berkeley.edu/ burgmann/EPS216/rheolog y.html/ (4 Juli 2017)

http://www.geo.arizona.edu/geo5xx/geo519.071/lectur es/Rheology.pdf/ (4 Juli 2017)

http://www.webpages.uidaho.edu/ simkat/geol345_file s/Lec3_Rheology.pdf/ (4 Juli 2017) 